\title{
On a Tornaria found in British Seas.
}

\author{
By
}

Gilbert C. Bourne, M.A., F.L.S.,

Fellow of New College, Oxford, and Resident Director of the Association.

With Plates VII, VIII.

Before 1888 no specimen of Tornaria, the well-known pelagic larva of Balanoglossus, had been taken off the English Coast. But on August 9th of the past year Mr. Weldon, using the surface net near the Eddystone Lighthouse, took several young specimens of Tornaria, and subsequently the same gentleman, during a cruise of a week's duration towards the end of August, captured many larger and more mature specimens of the same larva. Other specimens were taken by us up to September 21st, and in the month of August Mr. Rupert Vallentin found several specimens in the vicinity of Falmouth.

The specimens taken on these occasions form the subject of the present memoir, and their anatomy is detailed at some length, both because of the interest attached to a form hitherto unknown to England, and because it is in some respects of morphological importance.

The specimens taken by us came from the offing, and were not taken within four miles of the shore; Mr. Vallentin's Tornaria were found close to the shore at Falmouth. As he was able to bring his back alive and preserve them at leisure in his laboratory, they are better preserved than those taken by us, since we were obliged to preserve our catch in a somewhat rough manner out at sea. An examination of Mr. Vallentin's specimens leaves me no doubt that the larva is Tornaria Kröhnii, a species found in the Mediterranean. The different forms of Tornaria have not been with certainty referred to their adult forms, but $T$. Kröhnii must belong to one of the Mediterrsnean species of Balanoglossus, that is to say, to $B$. Kowalevskii, $B$. minutus, or $B$. claviger, species which have not hitherto been recorded from the English Channel, unless we suppose that the larva of $B$. salmoneus $v$. sarniensis, which occurs in the Channel Islands and at Roscoff, is identical with Tornaria Kröhnii.

The larvæ found on August 9th were of minute size, the largest 
measuring not more than $.33 \mathrm{~mm}$. in length. In the same surface net I found a few specimens of a younger larva which is identical with Johannes Mülier's figure of the youngest Tornaria found by him. One of these larvæ is shown in fig. 1. It has a pre-oral ciliated band and a longitudinal band, but the circumanal band is not developed. The anus is terminal and the mouth opens on the ventral surface. A longitudinal section of this larva is shown in fig. 2. The segmentation cavity is large, and in its anterior portion are several scattered amœboid cells, which will form the walls of the anterior body-cavity. The mouth leads into a stomodæum which is not yet in communication with the gut. The gut is divided into two regions, an anterior mid-gut and a posterior hind-gut, the latter opening to the exterior by the anus. The opening of the anus is shown in fig. 3. It seems probable from the condition of the larva that the posterior division of the gut is not a proctodæum, as might be supposed from an examination of the perfect Tornaria, and that the blastopore persists as the anus without being pushed further inwards by a secondary invagination of ectoderm, i.e. a proctodæum.

The next stages observed have all the characters of a Tornaria. The circumanal ciliated ring is now fully developed, but has not the same importance that it acquires at a later stage. The pre-oral and longitudinal bands retain the same arrangement, but are more marked than they were in the earliest stage (fig. 4). The gut is increased in size and is more distinctly differentiated into a mid-gut and a hind-gut. The anterior body-cavity is formed, probably from the amœboid cells described in the earlier larva, and is connected by a muscular thread with the now conspicuous apical sense organ. It opens on the dorsal surface by a pore, which eventually becomes, as Spengel* has shown, the proboscis pore of the adult. Anticipating its fate I shall refer to this pore as the proboscis pore. Fig. 12 shows a longitudinal section through a Tornaria of this age. It can be seen that the œsophagus opens into the gut, the point of junction between the two being sharply defined. The cells of the œsophagus are columnar and richly ciliated. In larvæ of this age the opening from the mid-gut into the hind-gut is very small and difficult to find in specimens contracted by reagents. At first I was led to believe that no communication between the two exists at this stage, but further examination showed me that an opening exists as shown in fig. 5. No traces of the so-called heart (the proboscis sac of Bateson) nor of the collar- and body-cavities are to be found at this stage. The third stage shown in fig. 13 represents the perfect Tornaria. The larva has increased greatly in size, the specimen from which the figure was drawn was as much as a millimetre in

* Bau u. Entwicklung von Balanoglossus, Tagebl. d. Naturf. Vers. München, 1877. 
length; but in this respect there is great variety among individuals. The pre-oral and longitudinal bands have undergone considerable changes both in their arrangement and in histological characters. In the earlier larva the pre-oral band was triangular, the base overhanging the mouth, and the apex touching the apical sense organ. In this stage the external angles of the triangle are drawn out on either side into long loops which are turned upwards towards the apex, the remainder of the figure appearing as a third median loop which touches the sense organ. The lower edge overhanging the mouth has not undergone any change. The longitudinal band forms a sort of cross the head of which touches the sense organ, the arms are turned upwards like those of pre-oral band. Ventrally the angle beneath the mouth is larger and more sharply defined, but otherwise no important change has taken place. In section, both the pre-oral and longitudinal bands are seen to be composed of numerous densely-crowded, deeply-stained nuclei, the cell outlines of which are not distinguishable. In the earlier stage the cells of the bands were columnar and fewer in number. The cilia have nearly disappeared in the later stage, but a few fine patches may be distinguished. The circumanal band on the other hand has increased in size and importance, and is now the chief if not the only organ of locomotion. Its long and powerful cilia are borne on long columnar cells arranged in oblique rows of three, as is shown in fig. 11. Above and below the ciliated cells are supported by packing cells, and numerous spots of bright brown pigment mark the course of this as well as of the pre-oral and longitudinal bands. Each ciliated cell is long and columnar, slightly contracted in the middle of its length, with a large nucleus. The cilia can be traced as fine fibrillæ inwards as far as the nucleus, but I could not determine whether they entered the nucleus or not.

The alimentary tract does not require a detailed description. The chief distinction between this stage and the last consists in the large circular aperture between the mid-gut and hind-gut. The anus remains relatively small.

The anterior body-cavity, which from its fate may conveniently be spoken of as the proboscis cavity, shows the same relations as in the previous stage. The whole cavity is larger, and its walls are further differentiated, the anterior wall being considerably thickened. Between the thickened portion and the point of insertion of the œsophagus on the mid-gut a few scattered cells may generally be distinguished.

The "heart" of Agassiz, Metschnikoff, and Spengel makes its appearance at this stage as a vesicle lying just above and to one side of the proboscis pore. Figs. $6-10$ are a series of sections vol. II, NO. I. 
through the region of the proboscis pore in a perfect Tornaria. In fig. 6 two canals may be seen lying side by side. Of these, one marked ant.b.c. is the canal of the proboscis cavity leading to the proboscis pore. The other, marked $v$., is the heart in question. An examination of figs. 7 and 8 shows that it is formed as an invagination of the ectoderm just above and to one side of the proboscis pore $(d . p$.). Prof. Spengel, who has investigated the whole development of many species of Tornaria, has been good enough to send me proofs of the illustrations of his forthcoming monograph on Balanoglossus, and from his figures and from the account given in his preliminary paper $(d)$ it appears that this vesicle is destined to form the "heart" in the adult animal, the proboscis sac of Bateson.

By permission of Mr. Weldon I reproduce a drawing (fig. 19) of the proboscis gland in a later stage of the Tornaria found by him in the Bahamas. In this the heart or proboscis sac $(v$.) is seen as a sac lying in the proboscis gland. It is completely closed, and does not communicate with the blood system nor with the proboscis cavity. The most plausible explanation of this structure is that the anterior body-cavity of Balanoglossus may primitively have been a paired structure, and that this sac may be a member of the pair and the degenerated fellow of the proboscis cavity. But the development of a mesoblastic pouch as an invagination of the ectoderm lands us in a great morphological difficulty.

The development of the posterior mesoblastic pouches can be followed up to a certain point in this stage. It has already been shown by Metschnikoff and Agassiz that a plate is budded off from the posterior region of the gut on each side, which subsequently undergoes division, and forms, as shown by Spengel, the collarcavities and body-cavities of the adult. My sections show that right and left of the body a plate of cells is budded off from the upper edge of hind-gut on either side. At first continuous with the hind-gut (fig. 14), each plate subsequently separates from it, and becomes so closely applied to the mid-gut as to look as if it had originated from it (fig. 15). The cells composing these plates multiply, and a cavity is formed in them, as shown in fig. 16 . No later stages were observed in our Tornaria, but in other forms these pouches become each divided into an anterior and a posterior portion, the anterior moiety on each side giving rise to the collarcavity of the adult, the posterior moiety to the general body-cavity. This further development is figured in the drawings which Prof. Spengel has sent me, and I was able to follow it in the series of preparations of the Bahamas Tornaria lent me by Mr. Weldon.

Bateson, in his account of the development of Balanoglossus 
Kowalevskii, describes the collar- and body-cavities as arising from separate pairs of archenteric pouches. The account given above, which was first given by Metschnikoff and has since been proved by Spengel, is in accordance with Bateson's observations, if I am right in considering that the hind-gut is in reality a portion of the true gut and not a proctodæum. But although I believe that the evidence at my disposal is opposed to the view that this region of the alimentary tract is a proctodæum, Prof. Spengel informs me that he is inclined to think that it is, and should he prove to be correct, the origin of the mesoblast from such a source would be without parallel in the animal kingdom. I expect to find that my view is correct, because a widely different origin of the mesoblast in two species of the same genus is in itself hardly credible, and would present most serious morphological difficulties.

The apical sense organ in our Tornaria is shown in section in fig. 18. Its central portion is composed of columnar sense-cells bearing cilia. Outside of these are larger cells, with large nuclei surrounding a pair of deeply pigmented pits. These pits are the "eye-spots" of previous authors, the large cells surrounding them are probably ganglion-cells. Beneath the sensory cells is a thin layer of nerve-fibres. The structure of the sense organ and its relation to the muscular band which connects it with the proboscis cavity can readily be seen in fig. 18. The paired invaginations forming sense pits, suggest a comparison with similar organs in the unarmed Gephyrea.

Unfortunately, the account of the British Tornaria must stop here. No specimens older than that described were taken during the year. Possibly if we had brought back our Tornaria alive we might have succeeded in rearing the further stages as was done by Metschnikoff and Agassiz, but owing to the distance we had to traverse in a small sailing-boat, and that often in calm weather, we found it always expedient to preserve our catch on board. Very probably the Tornaria ceases to lead a pelagic life, sinks to the bottom, and undergoes its further development there, which would explain our taking no later stages in the tow-net.

In conclusion, I have to thank Prof. Spengel for his kindness in sending me proofs of his forthcoming illustrations of the development of Balanoglossus. From these it appears that he has already anticipated anything that is new in this paper, such as the formation of the "heart" and the structure of the sense organ. I am also indebted to Mr. Weldon for lending me numerous drawings and preparations of the two forms of Tornaria found by him in the Bahamas, and to Mr. Rupert Vallentin for the specimens taken by him at Falmouth. 


\section{DESCRIPTION OF PLATES VII, VIII,}

\section{Illustrating Mr. G. C. Bourne's paper on "A Tornaria found in British Seas."}

FIG. 1.-Lateral view of a very young Tornaria (?).

Fra. 2.-Longitudinal section through the same specimen, showing the relation of the stomodæum to the gut.

FIG. 3.-Posterior part of the next section to 2, showing the blastopore persisting as the anus.

Frg. 4.-Young Tornaria, older than fig. 1 . Actual size $\cdot 33 \mathrm{~mm}$.

Fig. 5.-Frontal section through the posterior region of a Tornaria of the same age as fig. 4, to show the communication between the mid-gut and the hind-gut.

Figs. 6, 7, 8, 9, 10.-Five consecutive sections through a perfect Tornaria in the region of the proboscis pore, showing the opening of the latter (d.p.) and the canal (ant.b.c.) which connects it with the proboscis cavity. In figs. $6,7,8$, the mode of origin of the socalled heart $(v$.) may be seen.

FIG. 11.-Surface-view of the circumanal ciliated ring, showing the nuclei of the ciliated cells, the supporting cells, and the pigment spots.

FIG. 12.-Sagittal section through a Tornaria of the same age as fig. 4, showing the proboseis eavity and pore.

FIG. 13.-Lateral view of a perfect Tornaria, showing the complication of the ciliated bands. Actual size $1 \mathrm{~mm}$.

FIG. 14.-Longitudinal section through the posterior region of a Tornaria of the same age as fig. 3, showing the origin of the mesoblast from the hind-gut.

FIG. 15.-Longitudinal section through a somewhat more advanced larva, showing the mesoblast separate from the hind-gut, and closely applied to the wall of the mid-gut.

FIG. 16.-Transverse section of a larva somewhat older than fig. 15. A cavity has been formed in the mesoblast.

Fig. 17.-Surface view of the ectoderm in a perfect Tornaria.

Fig. 18.-Frontal section through the apical sense organ, showing the sense pits (s.p.), the ganglion-cells and layer of nerve-fibres, the proboscis cavity, and the muscle band connecting the latter with the sense organ.

FIG. 19.- Section through the proboscis gland of an advanced larva of a Balanoglossus from the Bahamas, showing the relations of the so-called heart (proboscis sac) to the proboscis gland. Copied from a drawing by Mr. Weldon.

\section{Lettering in the above figures.}

a. Lateral loop of the pre-oral band. $a^{\prime}$. Median loop of the pre-oral band. $a^{\prime \prime}$. Lateral loop of the longitudinal band. $a^{\prime \prime \prime}$. Median loop of the longitudinal band. $a$. $b$. Circumanal ciliated band. am.c. Amœboid cells. an. Anus. ant.b.c. Proboscis cavity. d.p. Proboscis pore. ect. Ectoderm. end. Endoderm. g.c. Ganglion-cells. h.g. Hind-gut. l.b. Longitudinal band. m. Mouth. m.b. Muscular band. mes. Mesoblast. m. g. Midgut. n.f. Layer of nerve-fibres. aes. Esophagus. pr. b. Pre-oral band. proc. Proctodæum. p.s. Pigment spots. s.c. Supporting cells. s. o. Apical sense organ. s. $p$. Sense pits. v. "Heart," or proboscis sac. 


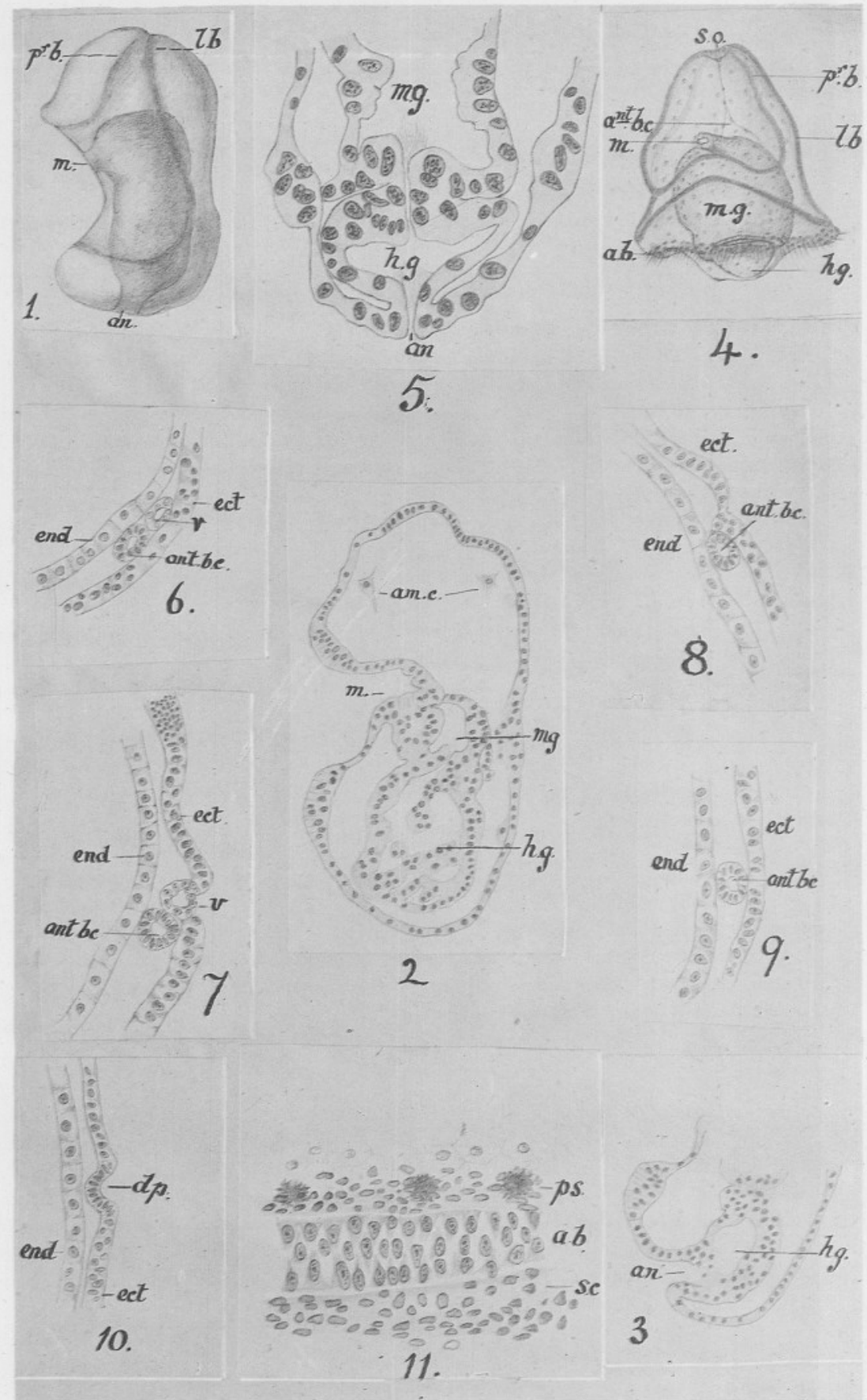




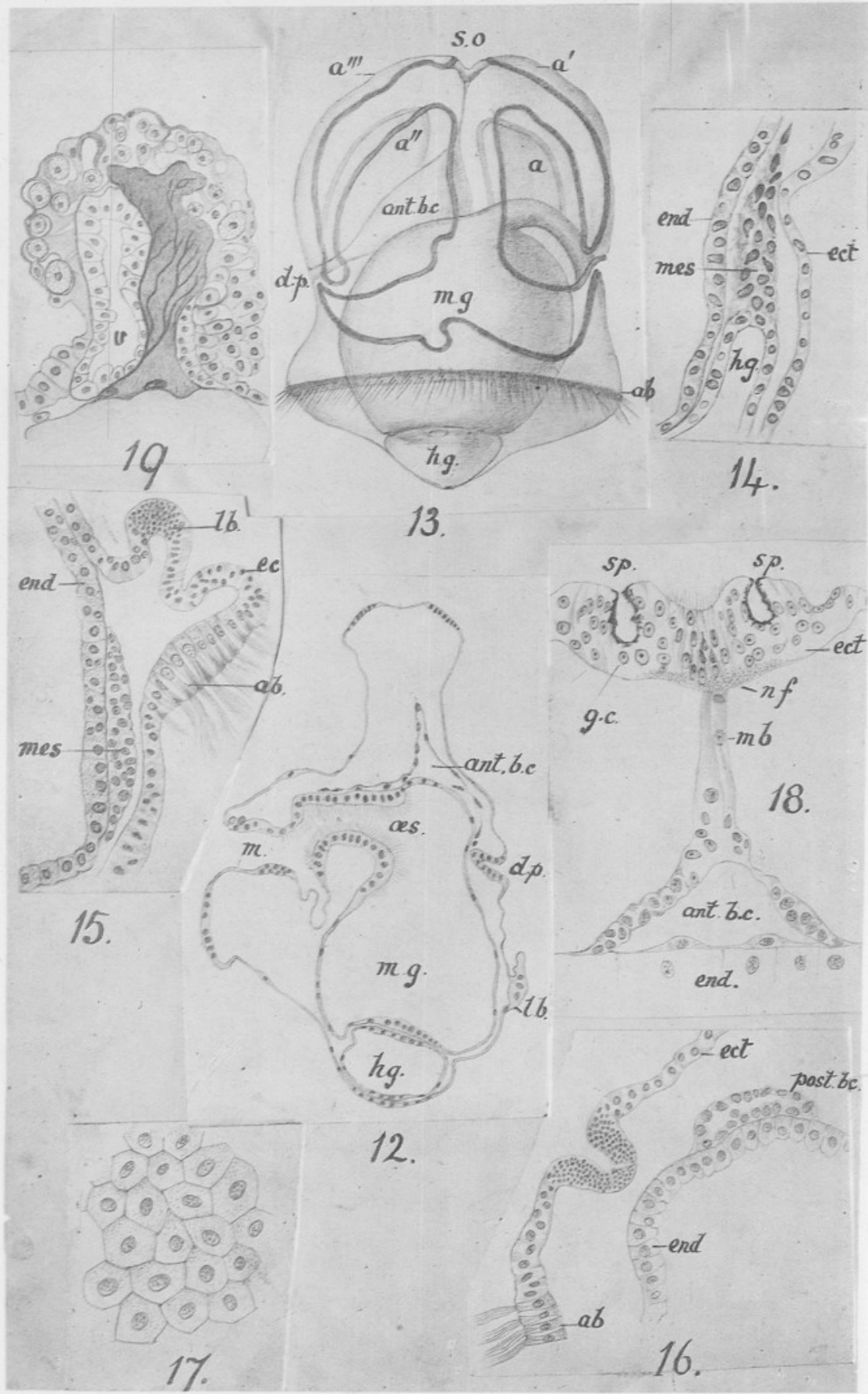

